\title{
Linking employer branding orientation and firm performance: Testing a dual mediation route of recruitment efficiency and positive affective climate
}

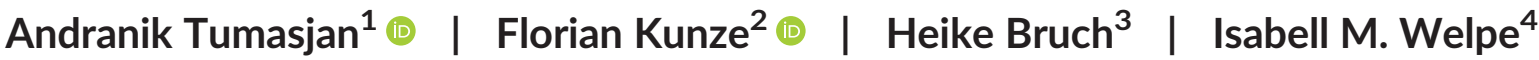

\author{
${ }^{1}$ Johannes Gutenberg University Mainz, Mainz, \\ Germany \\ ${ }^{2}$ University of Konstanz, Konstanz, Germany \\ ${ }^{3}$ University of St. Gallen, St. Gallen, \\ Switzerland \\ ${ }^{4}$ Technical University of Munich, Munich, \\ Germany

\section{Correspondence} \\ Andranik Tumasjan, Johannes Gutenberg \\ University Mainz, Jakob-Welder-Weg 4, Mainz \\ 55128, Germany. \\ Email: antumasj@uni-mainz.de
}

\begin{abstract}
Faced with competitive labor markets, firms increasingly use employer branding to build a qualified workforce and engage their employees. However, our understanding of the impact of employer branding orientation on firm performance and the theoretical firm-level mechanisms underlying this potential impact is very limited. To address this gap, we integrate brand marketing theory with human resource management (HRM) research to develop a model explicating how employer branding orientation is linked to firm performance through a dual route by enhancing both recruitment efficiency (i.e., external route: applicants) and positive affective climate (i.e., internal route: incumbent employees). The results of a multisource study (i.e., top management, human resource managers, employees) with 93 firms show employer branding orientation is positively related to firm performance through positive affective climate but not recruitment efficiency. Using a brand equity approach to HRM, our results advance the literature by demonstrating the generalizability of employer branding effects independent of concrete brand attributes and explaining the firmlevel mediating mechanisms linking it to firm performance.
\end{abstract}

KEYWORDS

employer branding, firm performance, human resource management, positive affective climate, recruitment

\section{INTRODUCTION}

Building, sustaining, and engaging a qualified workforce is crucial for organizational success and therefore one of the most important goals of human resource management (HRM; Collings \& Mellahi, 2009; Taylor \& Collins, 2000). To attract and engage employees in increasingly competitive labor markets, many firms have started to strategically manage their employer brand, both externally toward potential applicants and internally toward incumbent employees (Martin, Gollan, \& Grigg, 2011). Building on concepts from brand marketing, this integrated HRM approach has been termed employer branding, which aims at "internally and externally promoting a clear view of what makes a firm different and desirable as an employer" (Lievens, 2007: p. 51).
While employer branding is a concept that resides at the firm-level of analysis, prior research has mainly investigated employer branding antecedents and outcomes at the individual-level of analysis (for review, see Theurer, Tumasjan, Welpe, \& Lievens, 2018). This is a major limitation because "[f]indings at one level of analysis do not generalize neatly and exactly to other levels of analysis [...] and therefore [t] blindly generalize findings across levels of analysis is to commit a fallacy" (Kozlowski \& Klein, 2000, p. 213). Thus, the current state of research-showing that employer branding has positive effects on individual level outcomes-does not allow generalizing to potentially positive effects at the firm level. Therefore, it remains theoretically unclear whether employer branding actually influences firmlevel outcomes (Francis \& Reddington, 2012). 
Relatedly, whereas extant conceptual propositions (e.g., Backhaus \& Tikoo, 2004) speculate that employer branding will have positive firm-level effects, the current empirical literature is surprisingly silent on employer branding's effects on firm-level mediating mechanisms and outcomes (Theurer et al., 2018, notable exceptions include Turban \& Cable, 2003; Collins \& Han, 2004). Finally, the overwhelming majority of employer branding research has focused on the role of employer branding in the very early applicant generation phase (e.g., Collins \& Stevens, 2002; Holtbrügge, Friedmann, \& Puck, 2010; Tumasjan, Strobel, \& Welpe, 2011). In this vein, extant research has mainly concentrated on identifying concrete employer brand attributes (e.g., prestige or location; Cable \& Graham, 2000; Lievens \& Highhouse, 2003; Moser, Tumasjan, \& Welpe, 2017; Van Hoye, Bas, Cromheecke, \& Lievens, 2013) rather than testing a generalizable model of employer branding and its effects at the firm level. Thus, from a firm's perspective it is currently unclear if and how employer branding translates into firm performance (Sung \& Choi, 2014). Recognizing these limitations, scholars have called for research addressing the effects of employer branding on firm performance and investigating the underlying mechanisms of this effect (e.g., Ambler \& Barrow, 1996; Phillips \& Gully, 2015) in order to "identify the mediators that operate between the employer branding program and the firm's profit margin or profit growth" (Backhaus \& Tikoo, 2004, p. 512).

To address this unresolved puzzle in the current literature, we reconceptualize the extant approach to studying employer branding by introducing the construct of employer branding orientation. As an overarching HR guiding principle at the firm level (Becker \& Gerhart, 1996), the construct reflects the notion of firms putting a high value on employer brand building by seeking to actively promote the employer brand externally and internally. Hence, we argue, on the one hand, employer branding orientation facilitates building a distinct and an attractive external employer image (Lievens, 2007), which may lead to improved recruitment efficiency, such as the time to hire and cost per hire (Laumer, Maier, \& Eckhardt, 2015; Ulrich, 1997). On the other hand, employer branding orientation may also positively impact incumbent employees' positive affective climate, that is, "the shared experience of positive affect within an organization" (Menges, Walter, Vogel, \& Bruch, 2011, p. 894). Ultimately, we assume that both improved employee recruitment efficiency and positive affective climate will enhance firm performance (Jiang et al., 2012; Shaw, Gupta, \& Delery, 2005).

We make four major contributions to the literature. First, integrating branding theory from the field of marketing with HRM research, we reconceptualize employer branding as a guiding "HR principle" (Becker \& Gerhart, 1996), by introducing the concept of employer branding orientation, capturing the extent to which firms uphold employer branding as a principle that is strategically important to build employer brand equity (Collins \& Stevens, 2002), to the literature. Thereby, we build and test theory at the firm-level of analysis and advance employer branding research which currently bases almost all firm-level claims on individual-level studies (e.g., Han \& Ling, 2016; for review, see Theurer et al., 2018).
Second, by conceptualizing and measuring employer branding at the level of a guiding HR principle (Becker \& Gerhart, 1996), we advance extant research by making it possible to empirically test the generalizability of employer branding effects beyond concrete attributes. Prior research has conceptualized employer branding in terms of concrete brand attributes (e.g., "sincerity" or "ruggedness"; Lievens \& Highhouse, 2003; see also Aaker, 1997; Aaker \& Fournier, 1995) residing at the concrete "HR practice" level (Becker \& Gerhart, 1996), and, therefore, their effect may be contingent on specific firm characteristics. Thus, it is not clear from extant studies whether employer branding can be considered part of "best practice" HR approaches from a so-called "universalistic" theoretical viewpoint as conceptualized by Delery and Doty (1996). We hence contribute to the literature by showing how employer branding's effects may be conceptualized at the guiding-principle level (Becker \& Gerhart, 1996).

Third, addressing several calls in the literature, we explicate firmlevel mechanisms underlying the effect of employer branding on firm performance (Backhaus \& Tikoo, 2004). Our study yields a novel explanation for how employer branding orientation influences firm performance through its impact on different key HR performance indicators (i.e., recruitment efficiency and positive affective climate) in different target groups (i.e., potential employees and current employees).

Fourth, we advance the field by investigating whether and how employer branding impacts employees' collective emotions as repeatedly suggested in the literature (e.g., Lievens \& Slaughter, 2016). Since employer branding aims at creating positive emotional responses in its target groups, it is surprising there is a dearth of research on emotional outcomes (Rampl, 2014). To address this limitation, we theorize and test how employer branding influences positive affective climate as a mediating mechanism for its impact on firm performance.

\section{THEORY AND HYPOTHESIS DEVELOPMENT}

\subsection{Employer branding and firm-level outcomes}

In the past decades, a literature stream integrating research from the field of marketing with HRM research has been emerging, mainly focusing on the notion of brands and branding in HRM (Martin, Beaumont, Doig, \& Pate, 2005; Russell \& Brannan, 2016; Timming, 2017). At the core of this stream is the insight that brands, branding, and reputation play an important role in HRM and may influence key HRM processes and outcomes (Edwards, 2017; Theurer et al., 2018). In their seminal article, Ambler and Barrow (1996) conceived employer branding as an application of brand marketing principles to improve key HR outcomes, such as applicant attraction, recruitment efficiency, and current employees' engagement, to ultimately increase firm performance. In short, employer branding usually involves a three-step process (Backhaus \& Tikoo, 2004; Lievens, 2007). First, firms create a unique and differentiating employer value proposition, which serves as the central message positioning the value that the firms offer to their employees (Backhaus \& Tikoo, 
2004), such as organizational culture, leadership styles, and employment benefits (Backhaus \& Tikoo, 2004; Dineen \& Allen, 2016). In the second and third steps of the employer branding process, the employer value proposition is marketed to potential applicants and promoted to incumbent employees (Backhaus \& Tikoo, 2004; Francis \& Reddington, 2012; Lievens, Van Hoye, \& Anseel, 2007). Thus, the goal of employer branding is to position the employment experience as attractive and distinctive from other employers (Lievens, 2007) and to promote it to both an external (labor market) and an internal (firm) audience to enhance key HR outcomes and, as a result, contribute to firm performance.

The existing employer branding literature has mainly investigated the attributes that make up employer brands from the applicants' perspective (e.g., Lievens \& Highhouse, 2003), the influence of recruitment practices on applicants' employer images (e.g., Collins \& Han, 2004), and the influence of employer brands on early-stage applicant outcomes (e.g., Collins \& Stevens, 2002).

In what has become the dominant employer branding framework, Lievens and Highhouse (2003) have conceptualized employer brands as consisting of instrumental (e.g., pay, benefits, or career advancement) and symbolic (e.g., prestige, innovativeness or competence; Lievens, 2007) employer image attributes. Building on this framework, most employer branding studies have investigated the concrete attributes of employer brands (e.g., Berthon, Ewing, \& Hah, 2005; Edwards \& Edwards, 2013) and their influence on potential applicants' reactions at the individual level, such as perceived organizational attractiveness and job choice intentions (e.g., Baum \& Kabst, 2013; Collins \& Stevens, 2002).

However, while these studies provide valuable insights on the effects of different brand attributes from the applicants' perspective, a key issue from the firm-level perspective (i.e., HRM and general management) is whether and how employer branding actually translates into tangible desired HR outcomes, such as enhanced employee recruitment and engagement, that in turn contribute to firm performance (Backhaus \& Tikoo, 2004). Some studies have started to investigate the effects of employer reputation and recruitment practices on employer brand awareness and employer image on firm-level outcomes. However, these studies focused solely on applicant outcomes, such as applicant pool quantity and quality (e.g., Cable \& Turban, 2003; Collins \& Han, 2004; Dineen \& Williamson, 2012) rather than incumbent employees. Thus, while there are a few studies investigating the influence of employer branding on incumbent employees at the individual level of analysis (e.g., Hanin, Stinglhamber, \& Delobbe, 2013; Lievens et al., 2007), research on employer branding's impact on incumbent employees at the firm-level is scant. In this vein, Gardner, Erhardt, and Martin-Rios (2011) have called researchers to investigate the impact of employer branding on incumbent employees. Similarly, a major limitation constitutes the dearth of research on employer branding's effects on firm performance and the underlying mediating mechanisms (Theurer et al., 2018) which we will focus on in the next sections.

\subsection{Employer branding orientation as a guiding HR principle at the firm level}

To address the question if and how employer branding translates into these firm-level outcomes, we introduce the concept of employer branding orientation to the literature. In marketing research, brand orientation describes "an approach in which the processes of the organization revolve around the creation, development, and protection of brand identity in an ongoing interaction with target customers, with the aim of achieving lasting competitive advantages in the form of brands" (Urde, 1999, p. 117). Applying this concept to employer branding, we define employer branding orientation as an approach in which the HRM processes revolve around the creation, development, and protection of employer brand equity in an ongoing interaction with potential and incumbent employees to achieve sustainable competitive advantages in the labor market.

We conceptualize employer branding orientation as an overarching HR guiding principle (Becker \& Gerhart, 1996) reflecting an approach that applies "brand thinking to people management" (Mosley, 2014, p. 1). Such guiding principles describe firms' general HRM principles and reside at the most abstract level of an HR system (Posthuma, Campion, Masimova, \& Campion, 2013). Becker and Gerhart (1996) were among the first to distinguish between levels of abstraction in HR systems and reasoned that "it is at this level within the HR system that effects are 'generalizable or universal" (Monks et al., 2013, p. 380). Extant research has demonstrated that it is important to adopt a multiple level perspective to HRM and examine effects on their respective level as well as in a cross-level manner (Ostroff \& Bowen, 2000, 2004, 2016; Jackson, Schuler, \& Jiang, 2014; Paauwe, 2009; Peccei \& Van De Voorde, 2019; Renkema, Meijerink, \& Bondarouk, 2017).

Building on Becker and Gerhart's (1996) reasoning, we assume that specific employer brand attributes or contents (e.g., prestige, freedom, innovativeness) reside at the practice level of abstraction, and their effects on HR outcomes and firm performance may thus not be generalizable across contexts (Becker \& Gerhart, 1996). Thus, conceptualizing employer branding orientation as a general guiding principle allows us to study the influence of employer branding independent of concrete policies and practices (e.g., certain brand attributes, such as "excitement" or "sincerity") or reputation rankings (e.g., Fortune magazine), the use and resulting effects of which may depend on specific firm characteristics. For instance, "excitement" as an employer brand attribute may not work for every firm and being listed in Fortune reputation rankings may not be possible for small and medium-sized firms. Therefore, our novel conceptualization goes beyond employer brand attributes at the practice level toward conceptualizing employer branding at the level of a higher-order principle to examine whether its effects on firm-level outcomes are generalizable (Becker \& Gerhart, 1996; Colbert, 2004). In this regard, we follow the so called "universalistic" theoretical perspective (Delery \& Doty, 1996) which reflects the view that there are "best practices" that generally have positive effects on organizational performance (Becker \& Gerhart, 1996). Delery and Doty (1996) contrast the "universalistic 
perspective" with the "contingency" perspective and the "configurational" perspective, which posit that HR practices need to be consistent with a certain firm strategy (contingency perspective) or need to be placed in a certain constellation with other HR practices (configurational perspective) to successfully contribute to firm performance. In this sense, our study employs a "universalistic" theoretical perspective because we assume that more employer branding orientation will in principle always contribute to higher firm performance (irrespective of a certain firm strategy or certain HR practice configuration) than less or no employer branding orientation.

To explain why employer branding orientation leads to enhanced HR outcomes and increased firm performance, we use employer brand equity theory (e.g., Cable \& Turban, 2003; Theurer et al., 2018), which is based on the brand equity literature from marketing research (Keller, 1993; Keller \& Lehmann, 2006). Recently, Theurer et al. (2018) have adapted Keller and Lehmann's (2006) brand equity model to employer branding and HRM, creating the employer branding value chain model as an overarching theoretical framework. Based on this overarching theoretical framework, we argue employer branding orientation will lead to enhanced recruitment efficiency (applicant side) and higher levels of positive affective climate (incumbent employee side), which, in turn, increase firm performance. Figure 1 displays our conceptual model.

\subsection{Employer branding orientation: Effects on recruitment efficiency and positive affective climate}

In the HRM literature there is significant debate about opening the "black box" between HRM activities and firm performance (see for reviews, Combs, Liu, Hall, \& Ketchen, 2006; D. Lepak, Liao, Chung, \&
Harden, 2006). Based on employer brand equity theory (Collins \& Stevens, 2002; Theurer et al., 2018), we therefore theorize on which mechanisms translate employer branding orientation into firm performance by considering a dual mechanism consisting of HR outcomes related to applicants (i.e., recruitment efficiency; "external route") and incumbent employees (i.e., positive affective climate; "internal route").

\subsubsection{Recruitment efficiency}

Building on previous work on applicant attraction, we hypothesize that employer branding orientation will be positively related to firms' recruitment efficiency (Backhaus \& Tikoo, 2004; Collins \& Stevens, 2002; Delery \& Roumpi, 2017). In particular, we argue that higher levels of employer branding orientation will improve the applicant pool, such that the share of employees that exhibit high levels of fit with the firm's needs will increase, which in turn will improve recruitment efficiency (Collins \& Han, 2004) for the following reasons.

Firms that actively market their employer brand and uphold it as an important value will create higher levels of positive employer brand awareness in their target group (Cable \& Turban, 2001, 2003). At the same time, high levels of employer branding orientation make it likely that firms successfully communicate a clear picture of what they stand for in terms of the employment experience, such as corporate culture, values, and employment conditions (Backhaus \& Tikoo, 2004). In turn, this communication should allow job seekers to make veridical comparisons between their own needs and values and the organization's culture and values (Braddy, Meade, \& Kroustalis, 2006). Thus, candidates perceiving fit with the employer brand will self-select to apply, whereas candidates that do not see a fit to the brand positioning will refrain from applying.

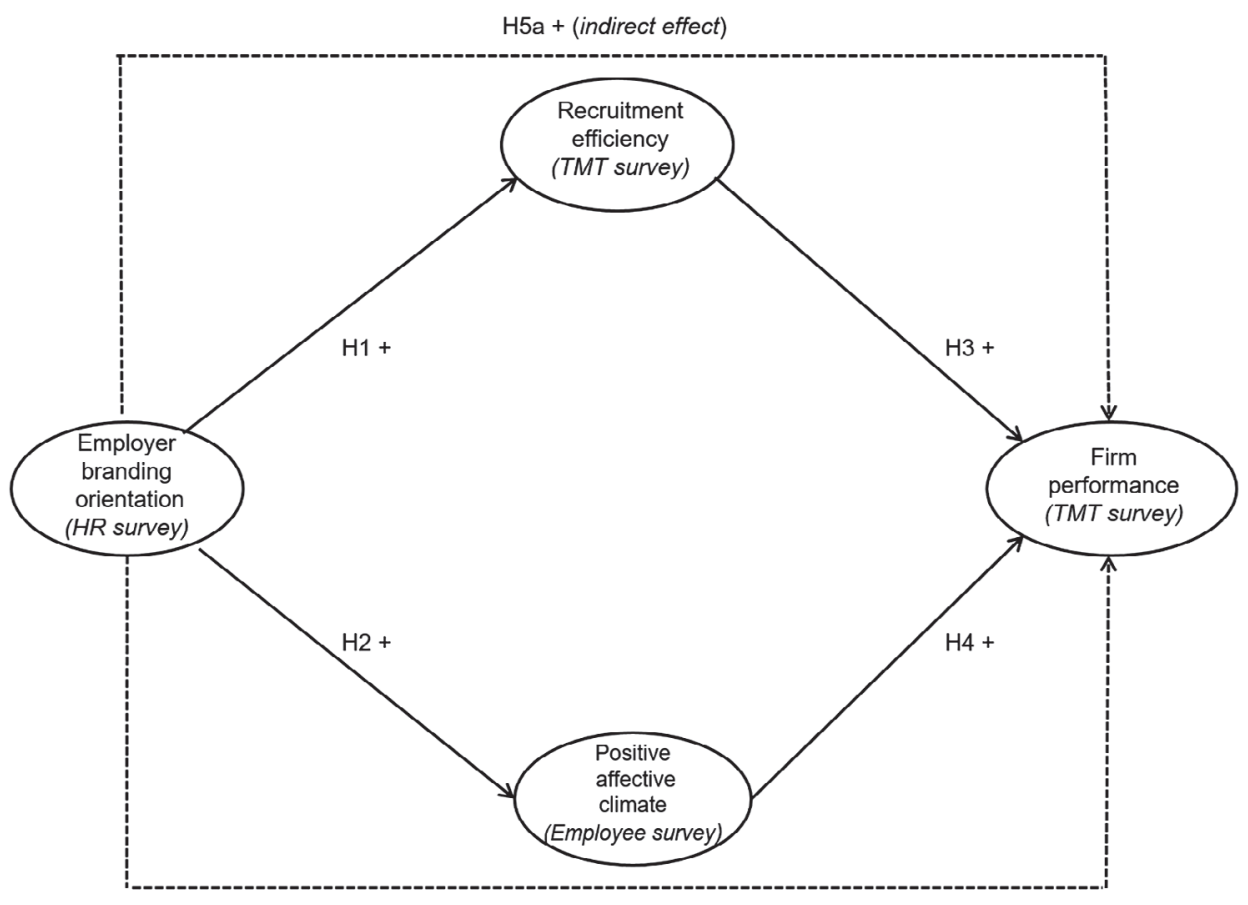

$\mathrm{H} 5 \mathrm{~b}+($ indirect effect) 
Therefore, higher levels of employer branding orientation will increase recruitment efficiency because the applicant pool will contain relatively more applicants that exhibit fit with the organization's culture and values, which will lead to less time and cost required to appropriately fill a position. In contrast, lower levels of employer branding orientation may lead to an applicant pool with lower levels of applicant-organization fit. In turn, the firm may require spending more time and resources per hire-for example because the firm will need to post further job advertisements if the applicant pool was insufficient in the first round of recruiting. In sum, higher applicant quantity and quality will result in more favorable levels of recruitment efficiency. Thus:

Hypothesis 1: Employer branding orientation will be positively related to recruitment efficiency.

\subsubsection{Positive affective climate}

We also hypothesize that employer branding orientation will be positively related to firms' levels of positive affective climate. Positive affective climate describes collective positive employee emotions and has been defined as "the shared experience of positive affect within an organization" (Menges et al., 2011, p. 894). Positive affective climate reflects collective emotions that emerge from individual employees' positive feelings and are transferred through sharing and contagion among employees (Knight, Menges, \& Bruch, 2018; Menges et al., 2011). While positive affective climate shares the aspect of positivity with constructs such as job satisfaction and organizational commitment, it is a distinct construct. First, positive affective climate is a group or organizational level construct rather than residing at the individual level. Second, positive affective climate is a purely emotional construct, whereas job satisfaction and commitment also reflect cognitive aspects (Knight et al., 2018; Menges et al., 2011).

Building on prior employer branding research (Lievens \& Slaughter, 2016) and branding research from marketing (Keller, 1993; Keller \& Lehmann, 2006), we propose that employer branding positively influences incumbent employees' positive collective emotional states, which will be reflected in positive affective climate at the aggregate firm level (Ashkanasy, Troth, Lawrence, \& Jordan, 2017; Menges et al., 2011), based on the following arguments.

First, employer branding orientation and the resulting employer brand equity will signal a favorable employer image to employees (Bangerter, Roulin, \& König, 2012). As a result, incumbent employees will likely perceive the employer image to be desirable, which will lead to higher levels of positive affect (Cable \& Turban, 2003; Hanin et al., 2013; Lievens et al., 2007). For instance, Hanin et al. (2013) showed positive effects of employer branding on affective commitment at the individual level of analysis. Moreover, the resulting employer brand equity (Keller, 1993) will foster employees' identification with their employer (Backhaus \& Tikoo, 2004; Edwards, 2010; Maxwell \& Knox, 2009), which has been shown to be related to higher levels of positive affect (Herrbach, 2006).
Second, individuals derive increased levels of self-esteem and social status from membership in an organization with an attractive and salient employer brand (Backhaus \& Tikoo, 2004; Cable \& Turban, 2001, 2003; Edwards, 2010). Therefore, higher levels of employer branding orientation may enhance incumbent employees' perception of working for an attractive employer and will increase their social status and self-esteem (Lievens et al., 2007), which should also result in higher levels of positive affective climate. Moreover, prior research in marketing (Cheney, Christensen, Conrad, \& Lair, 2004; Christensen, 1997) suggests that firm branding messages may "instill pride among employees, enhance an internal esprit de corps and perhaps even stimulate motivation and productivity-developments" (Christensen, 1997, p. 206), which further supports a positive effect of employer branding orientation on positive affective climate.

Third, employer branding has been associated with increased activity in brain regions linked to positive emotions and the reward system (Rampl, Opitz, Welpe, \& Kenning, 2016). In particular, using functional magnetic resonance imaging, Rampl et al. (2016) showed that an employer brand that is attractive to an individual elicited higher level of activation in areas linked to positive emotions and the reward system compared to other employer brands. These results provide support for the link between employer branding and emotion elicitation (Rampl, 2014), which has also been shown in (consumer) branding research (Chaudhuri \& Holbrook, 2001; Thompson, Rindfleisch, \& Arsel, 2006).

We assume that these mechanisms at the individual level may become shared among firm members by translating via contagion and affective sharing socialization processes into firm-level affective climates (Knight et al., 2018) and thus propose:

Hypothesis 2: Employer branding orientation will be positively related to positive affective climate.

\subsection{HR outcomes and firm performance}

We now turn to our argumentation on the link between recruitment efficiency and positive affective climate on the one hand, and firm performance on the other hand.

\subsubsection{Recruitment efficiency}

Research directly linking recruitment or staffing efficiency and outcomes at the firm level is relatively scarce (Gully, Phillips, \& Kim, 2014; Martins \& Lima, 2006; Rao \& Drazin, 2002). In most of the numerous strategic HRM studies, the influence of recruitment practices on firm performance has been measured only as a part within HR systems, for example, within high-performance work systems (HPWS; e.g., D. P. Lepak \& Snell, 2002; Guest, Michie, Conway, \& Sheehan, 2003; Delery \& Roumpi, 2017; Saridakis, Lai, \& Cooper, 2017). For instance, Huselid (1995) examined recruitment within HPWS using one item assessing the number of qualified applicants per position. Terpstra and Rozell (1993) conducted one of the few studies linking effective staffing and firm performance, demonstrating 
that effective staffing is indeed related to profit and profit growth (see also Gully et al., 2014). Further evidence suggesting a positive effect of recruitment efficiency on firm performance comes from recent studies in the context of small and medium-sized companies. In this vein, Sheehan (2014) finds a positive association between the use of formal recruitment methods and financial performance as well as innovation, respectively. Similarly, Greer, Carr, and Hipp (2016) report that small firms' use of effective recruitment practices used in large firms positively influences perceptual firm performance. In a related study, Kim and Ployhart (2014) show that firms with more selective staffing have greater productivity and profit growth than firms with less selective staffing.

Accordingly, in line with the extant literature, we argue that recruitment efficiency may contribute to firm performance. Although efficiency within the HR function may not necessarily directly translate into increased firm value, HR efficiency can create value through its influence on efficient business operations. In this vein, Becker, Huselid, and Ulrich (2001) argue there may be a "clear line of sight between efficient HR recruiting processes and the firm's bottom line through HR's contribution to improved operating effectiveness" (Becker et al., 2001, p. 54). This notion is supported by firm case studies showing that recruitment efficiency (e.g., cost per hire, time to hire) contributes to the bottom line across different industries, such as banking, health care, and semiconductor industries (Schnars \& Kleiner, 2000). Thus:

Hypothesis 3: Recruitment efficiency will be positively related to firm performance.

\subsubsection{Positive affective climate}

We also propose that higher levels of positive affective climate will be related to increased levels of firm performance (Ashkanasy \& Dorris, 2017; Parke \& Seo, 2017). First, positive affective climate has been shown to relate to higher levels of aggregate employee productivity, task performance, and organizational citizenship behavior (Menges et al., 2011). This prior research has built on broaden-and-build theory (Fredrickson, 2003) to argue that positive affect will broaden employees' thought-action repertoire, reflected in broader mindsets, which result in an extended array of actions, such as explorative behaviors, novel ideas, and creative actions (Fredrickson, 2004; Menges et al., 2011). In turn, employees will be more likely to build enduring personal resources, such as physical, intellectual, and social resources (Fredrickson, 2004). Both broadened mindsets and actions as well as enduring personal resources will enable employees to achieve higher levels of productivity (Knight et al., 2018; Menges et al., 2011), contributing to increased firm performance. We follow this logic and prior empirical findings and assume that positive affective climate may also positively contribute to firm performance, which is strongly influenced by these employee-level behaviors.

Second, previous research has documented that positive affect positively influences employee performance (for review, see Menges \& Kilduff, 2015). For instance, a study by Tsai, Chen, and Liu (2007) shows that positive affect relates to task performance mediated by various desirable employee behaviors (e.g., task persistence, helping coworkers). Relatedly, positive affect has also been shown to increase creativity and innovative behaviors (Baas, De Dreu, \& Nijstad, 2008; Baron \& Tang, 2011), which also both may contribute to increased levels of firm performance (Rosenbusch, Brinckmann, \& Bausch, 2011). Supporting this link at the firm level of analysis, Patterson et al. (2004) have shown that different positive organizational climates are related to firm productivity. A similar link at the group level was found by Liu et al. (2014) demonstrating that positive workgroup emotional climate was associated with increased group performance. Finally, in their comprehensive review, Menges and Kilduff (2015) document a host of research showing group-shared emotions have a positive impact on the performance of both small and large groups. Therefore, we propose:

Hypothesis 4: Positive affective climate will be positively related to firm performance.

\subsection{Mediated relationship between employer branding orientation and firm performance through recruitment efficiency and positive affective climate}

In line with employer brand equity research (e.g., Backhaus \& Tikoo, 2004; Edwards, 2010; Theurer et al., 2018), our basic argument is that higher levels of employer branding orientation will not enhance firm performance directly but rather will do so through enhancing key HR outcomes that, in turn, influence firm performance. Building on prior marketing research (e.g., Wong \& Merrilees, 2008), we base our rationale underlying this mediation hypothesis on the insight that the adoption of an employer branding orientation (i.e., an intraorganizational inclination) does not necessarily directly result in increased firm performance (Wong \& Merrilees, 2008). Rather, employer branding orientation may only affect firm performance if it first results in enhanced HR outcomes as intermediating mechanisms. This reasoning is in line with a theoretical account of employer brand equity building (Cable \& Turban, 2001) in which HR principles do not directly lead to firm performance outcomes but indirectly lead to such outcomes through building brand equity, which manifests in enhanced applicant-related and employee-related outcomes.

There are further reasons why an employer branding orientation may not directly affect firm performance. First, employer branding orientation may take some time to develop in the firm and, thus, may fail to directly generate higher levels of firm performance. Additionally, a firm may adopt an employer branding orientation but may unsuccessfully implement the necessary operative employer branding activities; this will also fail to lead to the desired effects. We therefore argue that adopting an employer branding orientation lays the groundwork for brand success (Cable \& Turban, 2001) and that having such an orientation is necessary but not sufficient for achieving positive firm performance outcomes.

Thus, considering the extant literature, and based on the employer brand value chain model (Keller \& Lehmann, 2006; Theurer et al., 
2018), we assume employer branding orientation will be associated with recruitment efficiency and positive affective climate. In turn, both components will contribute to firm performance (Gerhart, 2007). As a consequence, we argue these two HR outcomes are the core theoretical mechanisms that translate employer branding orientation into firm performance. Building on this argumentation we propose an indirect, fully mediated effect between employer branding orientation and firm performance, leading to the following two mediation hypotheses:

Hypothesis 5a: The effect of employer branding orientation on firm performance will be mediated by recruitment efficiency.

Hypothesis 5b: The effect of employer branding orientation on firm performance will be mediated by positive affective climate.

\section{METHOD}

\subsection{Sample}

We collected data for this study in 93 German small and mediumsized firms. ${ }^{1}$ The companies participated in a benchmarking study on various HR practices and were recruited and surveyed by an external service provider. To be eligible for participating, companies had to be located in Germany and should not exceed 5,000 employees. The companies received a detailed benchmarking report on their HR practices in exchange for their participation, and could also use their benchmarking position for third-party employer branding activities (e.g., adding a specific label to their job advertisements). Some of the participating companies $(n=21)$ had missing values on some of the study's measures. To avoid potential nonresponse bias and increase the statistical power for our analyses we use an expectationmaximization technique to impute the missing values and to calculate all models with 93 firms.

The companies belonged to four different sectors: manufacturing (29\%); service (47\%), finance (7\%), and trade (16\%). A total of 16,254 employees participated in the overall survey (mean company size: 327 employees), representing an average within-organization response rate of $73 \%$ (range $3-100 \%, S D=25$ ). The participating employees (58\% male) were, on average, 39 years old $(S D=11.43)$ and had an average organizational tenure of 8 years $(S D=8.33$ ).

We applied a multisource data sampling approach to limit the likelihood that a common source bias (Podsakoff, MacKenzie, \& Podsakoff, 2012) might affect our results. Therefore, we used three data sources. First, we asked the top human resource manager in each firm to assess employer branding orientation and several of the control variables (i.e., industry sector). Second, we asked $25 \%(n=4,080)$ of all employees in each company (randomly selected) to assess the positive affective climate of the company. ${ }^{2}$ Third, we collected information on recruitment efficiency and firm performance from all members of the top management team (TMT) in each company. The average TMT size was three, and the TMT members were mainly male (87\%), had an average tenure of 13 years (SD $=8.92$ ), and were on average 48 years old $(S D=8.84)$. In 58 companies, more than one TMT member answered the questionnaire.

\subsection{Measures}

Unless stated otherwise, we used 7-point scales ( 1 = strongly disagree, 7 = strongly agree) for our measures. To justify aggregation procedures for the measures that were answered by multiple respondents, we inspected common statistical benchmarks such as the intraclass coefficient (ICC ${ }_{1}$ and ICC 2 ; Bliese, 2000) and $r_{\text {wg }}$ (James, Demaree, \& Wolf, 1984).

\subsubsection{Employer branding orientation $(\alpha=.84)$}

To measure this construct, we reconceptualized a brand orientation scale by Wong and Merrilees (2008). In particular, we developed the following four items: (1) Employer branding is essential to our HR strategy; (2) employer branding is essential in running this company; (3) long-term employer brand planning is critical to our future success; (4) employer branding flows through all of our HR activities. A separate confirmatory factor analysis (CFA) indicated good model fit properties $\chi^{2}=16.58, d f=2$; comparative fit index $[\mathrm{CFI}]=.91$, incremental fit index $[\mathrm{IFI}]=.91$, standardized root mean square error of approximation $[\mathrm{SRMR}]=.06$ ).

\subsubsection{Recruitment efficiency $\left(\alpha=.85, \mathrm{ICC}_{1}=.30\right.$, $\mathrm{ICC}_{2}=.64$; median $r_{\mathrm{wg}}=.85$ )}

Recruitment efficiency was assessed with two items, time to hire and cost per hire (Ulrich, 1997), which were answered by the TMT members of each company and were adopted from Münstermann, Eckhardt \& Weitzel (2009; see also Laumer et al., 2015: (1) We are satisfied with the average time between the identification of a vacancy and the fill of a vacancy and (2) we are satisfied with our average costs for filling a vacancy. If two or more TMT members provided responses, their answers were averaged and aggregated to the firm level.

\subsubsection{Positive affective climate $\left(\alpha=.94, \mathrm{ICC}_{1}=.16\right.$, $\mathrm{ICC}_{2}=.89$; median $r_{\mathrm{wg}}=.76$ )}

We measured positive affective organizational climate in line with existing affective climate measures in the literature (Knight et al., 2018; Kunze \& Menges, 2017; Menges et al., 2011). In more detail we used four items from the Job-Related Affective Well-Being Scale (Van Katwyk, Fox, Spector, \& Kelloway, 2000) to measure how often employees in their organization experience the respective positive affective states in their jobs on a 5 -point scale from 1 (never) to 5 (extremely often/always) (sample item: Employees in our company 
feel enthusiastic in their job). These items were then aggregated to the firm level of analysis. A separate CFA indicated good model fit properties $\left(\chi^{2}=6.41, d f=2 ; \mathrm{CFI}=.99, \mathrm{IFI}=.99, \mathrm{SRMR}=.02\right)$.

\subsubsection{Firm performance $\left(\alpha=.82, \mathrm{ICC}_{1}=.31\right.$, $\mathrm{ICC}_{2}=.64$; median $\left.r_{\mathrm{wg}}=.86\right)$}

In line with existing research (Kunze, Boehm, \& Bruch, 2011, 2013), firm performance was assessed by asking TMT members of each company to rate their firms regarding the following aspects of operational performance (i.e., effectiveness of business procedures, employee productivity, employee retention) and organizational performance (i.e., company growth, financial performance, return on assets). Consistent with other studies that used perceptual measures of firm performance in multi-industry samples (e.g., Delaney \& Huselid, 1996; Kunze et al., 2013; Wall et al., 2004), we asked respondents to assess their organization's effectiveness over the last six months compared to that of their main competitors within the same region and industry ( 1 = far below average; $7=$ far above average). If two or more TMT members had answered the question, their responses were averaged per question and aggregated to the organizational level of analysis.

\subsubsection{Controls}

We included twelve control variables, which might also affect our outcome measures. First, we used the 18-item reflective measure of high-performance work practices (HPWP) $(\alpha=.85)$ developed by Datta, Guthrie, and Wright (2005), which was answered by the top HR manager to control for these general HR practices. The scale captured numerous dimensions of HPWP, such as feedback and reward systems (sample item: How many of your employees receive formal performance appraisals and feedback on a routine basis? [in \%]); internal training measures (sample item: How many of your employees receive regular training for firm-specific capabilities? [in \%]); career systems (sample item: How many of your employees have been promoted to a higher hierarchal level since their employment? [in \%]); and recruiting measures (sample item: How many of your employees have been recruited based on proactive recruitment measures? [in \%]). Second, we controlled for the contextual ambidexterity consisting of adaptive and alignment oriented management systems by using the eight item scale of Gibson and Birkinshaw (2004) (sample item: The management systems in this organization evolve rapidly in response to shifts in our business priorities) that was answered by the top HR manager in each company $(\alpha=.85)$, to inspect if the adaption of the general management systems to complex goals affect firm performance beyond employer branding orientation. Third, in line with recent research that has investigated effects of organizational climates on performance (Barrick, Thurgood, Smith, \& Courtright, 2015), we controlled for a measure of CEO transformational leadership (TFL) behavior. To assess the construct, employees directly reporting to the CEO in the top management answered seven items (sample item: The CEO leads by example) based on the scale by Rubin, Munz, and
Bommer (2005). These items $(\alpha=.83)$ were averaged to form one overall CEO TFL score.

Fourth, firm size, reported by the top HR representative, was included as a control variable. Since this measure was skewed, we log transformed it. Fifth, we controlled for age diversity (operationalized through the standard deviation) and the mean age of the workforce, since prior studies (e.g., Kunze et al., 2011), have shown that workforce age configurations are important for organizational processes and outcomes. Sixth, we also accounted for the dynamism of the organizations' environment with a one item measure from Jansen, Van Den Bosch, and Volberda's (2006) scale (the conditions in our key markets change very often; 1 = totally disagree; 7 = totally agree) rated by the top HR representative. Seventh, we also incorporated information captured from the top HR representatives on the recruitment difficulties experienced by the firm with two items (How difficult is it for your company to recruit qualified personnel?; How difficult is it for your company to retain qualified personnel? 1 = very easy; 7 = very difficult) ( $\alpha=.66$ ), and the current economic situation in the local region of the company (How bad is the current economic situation in your region, compared to other regions in Germany?; 1 = very bad; 7 = very good), as both variables are likely to affect recruitment efficiency processes and company performance. ${ }^{3}$

Finally, we also controlled for the two main industry sectors in our sample-production and service-as dummy variables.

\subsection{Analytical techniques}

We used two analytical approaches to establish the measurement structure of our model and test our hypotheses. First, to establish the distinctiveness of our constructs and the overall measurement structure, we applied structural equation modeling (SEM) using the AMOS software package. Second, we used the PROCESS macro in SPSS developed by Hayes (2017) to test the hypothesized relationships based on estimates with heteroscedasticity robust standard errors and bootstrapping procedures to test for the indirect effects and performed multiple test for alternative model solutions. ${ }^{4}$

\section{$4 \quad$ RESULTS}

Table 1 displays the intercorrelations and descriptive statistics of the study variables. All focal relationships were in the expected directions.

\subsection{Measurement model}

Our hypothesized measurement model consisted of four latent constructs-employer branding orientation, recruitment efficiency, positive affective climate, and firm performance. To inspect the overall model fit, we report an absolute fit index-SRMR-and two incremental fit indices-CFI and IFI-as proposed for sample sizes smaller than 200 (Hu \& Bentler, 1999). To assess the overall model fit, we use commonly applied cut-off points of $<.08$ for the SRMR and $>.90$ for the comparative fit indices. Furthermore, we also report the Akaike 
TABLE 1 Descriptives and intercorrelations

\begin{tabular}{|c|c|c|c|c|c|c|c|c|c|c|c|c|c|c|c|c|}
\hline Variable & M & $S D$ & 1 & 2 & 3 & 4 & 5 & 6 & 7 & 8 & 9 & 10 & 11 & 12 & 13 & 14 \\
\hline 1 Employer branding orientation & 5.85 & .79 & & $.29 *$ & $.33 * *$ & .22 & & & & & & & & & & \\
\hline 2 Recruitment efficiency & 5.11 & 1.07 & $.23^{*}$ & & $.40 * *$ & $.31 *$ & & & & & & & & & & \\
\hline 3 Positive affective climate & 3.33 & .32 & $.34 * *$ & $.35 * *$ & & $.37 * *$ & & & & & & & & & & \\
\hline 4 Firm performance & 4.77 & .75 & .19 & $.30 * *$ & $.34 * *$ & & & & & & & & & & & \\
\hline $\begin{array}{l}5 \text { High performance work } \\
\text { practices (HPWPs) }\end{array}$ & 5.12 & 1.17 & .18 & -.02 & $.38 * *$ & .08 & & & & & & & & & & \\
\hline $\begin{array}{l}6 \text { Ambidextrous management } \\
\text { practices }\end{array}$ & 68.19 & 13.05 & .20 & -.01 & $.28 * *$ & $.35 * *$ & $.41 * *$ & & & & & & & & & \\
\hline $\begin{array}{l}7 \text { Transformational } \\
\text { leadership CEO }\end{array}$ & 3.46 & .37 & .13 & $.25^{*}$ & $.48 *$ & .16 & $.32 * *$ & $.30 *$ & & & & & & & & \\
\hline 8 Company size (log) & 4.96 & .67 & $.23 *$ & -.06 & $-.25 *$ & -.01 & -.01 & -.01 & -.11 & & & & & & & \\
\hline 9 Workforce mean age & 39.11 & 3.98 & -.05 & -.05 & -.20 & -.07 & .09 & $-.25 *$ & $-.17 *$ & .09 & & & & & & \\
\hline 11 Environmental dynamism & 5.24 & 1.55 & .20 & .00 & .01 & -.15 & -.01 & .19 & .17 & -.02 & -.10 & .04 & & & & \\
\hline 12 Local economic situation & 2.70 & 1.23 & .03 & -.11 & -.16 & -.05 & $.21 *$ & -.02 & -.04 & $.22 *$ & .15 & -.02 & -.08 & & & \\
\hline 13 Recruiting difficulties & 3.65 & 1.13 & -.18 & $-.35 * *$ & $-.22 *$ & -.10 & -.17 & .01 & -.10 & -.17 & -.12 & $-.23 *$ & .06 & .14 & & \\
\hline 14 Industry: Manufacturing & .29 & .46 & -.11 & -.09 & -.07 & -.08 & -.15 & $-.31 * *$ & -.13 & -.15 & -.01 & $.31 * *$ & -.07 & -.10 & .09 & \\
\hline 15 Industry: Service & .47 & .50 & .09 & -.02 & .14 & -.15 & -.11 & $.21 *$ & -.04 & -.11 & -.02 & $-.34 * *$ & -.04 & .04 & -.07 & $-.61 * *$ \\
\hline
\end{tabular}

Note: Latent correlations between study constructs are printed in bold.

$* p<.05 ; * * p<.01 ; * * * p<.001$ (two-sided).

Information Criterion (AIC; Akaike, 1987) to compare different model solutions, with lower values signifying a better model fit. As the recruitment efficiency measure had only two items, we restricted the factor loadings to equal values to obtain unbiased estimates through a potential Heywood case (Kenny, Kashy \& Bolger, 1998).

Based on the selected fit indices, our proposed measurement model showed good fit properties $\left(\chi^{2}=156, d f=99, \mathrm{CFI}=.94\right.$,

TAB LE 2 Latent correlations between study constructs

\begin{tabular}{|c|c|c|c|}
\hline Construct & Item & Loading & Error variance \\
\hline \multirow[t]{4}{*}{ Employer branding orientation } & 1 & $.73 * * *$ & $.44 * * *$ \\
\hline & 2 & $.80 * * *$ & $.36 * * *$ \\
\hline & 3 & $.87^{* * * *}$ & $.27 * * *$ \\
\hline & 4 & $.63 * * *$ & $.40 * * *$ \\
\hline \multirow[t]{4}{*}{ Positive affective climate } & 1 & $.98 * * *$ & $.01 *$ \\
\hline & 2 & $.93 * * *$ & $.02 * * *$ \\
\hline & 3 & $.83^{* * *}$ & $.04 * * *$ \\
\hline & 4 & $.86 * * *$ & $.03 * * *$ \\
\hline \multirow[t]{2}{*}{ Recruitment efficiency } & 1 & $.84 * * *$ & $.41 * * *$ \\
\hline & 2 & $.87 * * *$ & $.30 * *$ \\
\hline \multirow[t]{6}{*}{ Firm performance } & 1 & $.80 * * *$ & $.48^{* * *}$ \\
\hline & 2 & $.85 * * *$ & $.34 * * *$ \\
\hline & 3 & $.66 * * *$ & $.44 * * *$ \\
\hline & 4 & $.66 * * *$ & $.29 * * *$ \\
\hline & 5 & $.60 * * *$ & $.77 * * *$ \\
\hline & 6 & $.70 * * *$ & $.41 * * *$ \\
\hline
\end{tabular}

$* p<.05 ; * * p<.01 ; * * * p<.001$ (two-sided).
$\mathrm{IFI}=.94, \mathrm{SRMR}=.08, \mathrm{AIC}=230)$. Moreover, all standardized factor loadings were above .50 and significant at the $1 \%$ level (see Table 2). As shown in Table 3, we compared our measurement model to three alternative model solutions to establish discriminant validity for the study constructs. First, a model allowing the recruitment efficiency and the firm performance items to load on one factor (since both were obtained from the TMT members (alternative model 1) had a worse fit $\left(\Delta \chi^{2}=71, \Delta d f=2, p<.001\right.$, AIC $\left.=297\right)$. Second, a model in which the two mediators (recruitment efficiency and positive affective climate) were allowed to load on one common factor (alternative model 2) had a significantly worse fit $\left(\Delta \chi^{2}=64, \Delta d f=2, p<.001\right.$, AIC $\left.=290\right)$, indicating that the two factors were indeed different. Finally, a model with all items loading on one common factor (alternative model 3) was also fitting worse $\left(\Delta \chi^{2}=380, \Delta d f=5, p<.001, \mathrm{AIC}=600\right)$.

\subsection{Hypotheses testing}

\subsubsection{Main analyses}

Table 4 displays the regression analyses for testing Hypotheses 1-4. Supporting Hypothesis 1, model 1 shows that employer branding orientation is positively related to recruitment efficiency $(B=.31$, $t=2.44, p<.05)$. Furthermore, employer branding orientation is also positively related to positive affective climate $(B=.12, t=3.20$, $p<.01)$ as shown in model 2 and supporting Hypothesis 2. Recruitment efficiency, in contrast, is related to firm performance only at a marginally significant level $(B=.16, t=1.84, p=.07)$, hence not supporting Hypothesis 3. Additionally, model 3 shows in line with 
TABLE 3 Comparison of measurement models

\begin{tabular}{|c|c|c|c|c|c|c|c|c|c|}
\hline Model & $\chi^{2}$ & df & $\chi^{2 / \mathrm{df}}$ & $\Delta \chi^{2}$ & $\Delta \mathrm{df}$ & CFI & IFI & SRMR & AIC \\
\hline Hypothesized model & 156 & 99 & 1.58 & & & .94 & .94 & .08 & 230 \\
\hline $\begin{array}{l}\text { Alternative model 1: Recruitment efficiency and firm } \\
\text { performance one factor }\end{array}$ & 227 & 101 & 2.25 & $71^{* * *}$ & 2 & .86 & .86 & .11 & 297 \\
\hline $\begin{array}{l}\text { Alternative model 2: Recruitment efficiency and positive } \\
\text { affective climate one factor }\end{array}$ & 220 & 101 & 2.18 & $64 * * *$ & 2 & .87 & .87 & .11 & 290 \\
\hline Alternative model 3: All one factor & 536 & 104 & 5.15 & $380 * * *$ & 5 & .52 & .52 & .11 & 600 \\
\hline
\end{tabular}

Note: The three alternative measurement models are compared to the hypothesized measurement model. The lowest Akaike Information Criterion (AIC) value shows the best fitting model.

Abbreviations: CFI, Comparative Fit Index; IFI, Incremental Fit Index; SRMR, Standardized Root Mean Square Residual.

$* p<.05 ; * * p<.01 ; * * * p<.001$ chi-difference statistic compared to the hypothesized model.

Hypothesis 4 , that positive affective climate $(B=.66, t=2.11, p<.05)$ is positively related to firm performance.

Given these results, we further inspected whether recruitment efficiency and positive affective climate mediate the relationship between employer branding orientation and firm performance as postulated in Hypotheses 5a and 5b. For this purpose, 10,000 bootstrap samples were drawn within the PROCESS model. Not supporting Hypothesis 5 a there was no indirect effect of employer branding orientation on firm performance via recruitment efficiency within a $95 \%$ confidence interval $(B=.06$; $95 \%$ bias corrected confidence interval, $\mathrm{BCCl}[-.002, .149])$, but only within a $90 \%$ confidence interval, thus not supporting Hypothesis $5 a(B=.06 ; 90 \% \mathrm{BCCl}[.005, .128]$ ). Supporting Hypothesis $5 \mathrm{~b}$, the results indicated there was no direct, but a significant indirect effect of employer branding orientation on firm performance via positive affective climate within a $95 \%$ confidence interval $(B=.11 ; 95 \% \mathrm{BCCl}[.015, .235])$. In sum, these results indicate support for a mediation chain between employer branding orientation, positive affective climate, and firm performance, while our data do not support a mediation chain between employer branding orientation, recruitment efficiency, and firm performance.

\subsubsection{Alternative model testing}

To ensure the validity of our findings, we performed multiple alternative model tests. First, a model including only the significant control variables (i.e., that showed a positive relationship to either one mediator or firm performance in the correlation analysis) resulted in similar and significant (at a $5 \%$ level, two-sided) effects for all proposed relationships that were significant in the main analysis.

TABLE 4 Regression results

\begin{tabular}{|c|c|c|c|c|c|c|c|}
\hline \multirow[b]{3}{*}{ Variables } & & \multicolumn{2}{|l|}{ Model 1} & \multicolumn{2}{|l|}{ Model 2} & \multicolumn{2}{|l|}{ Model 3} \\
\hline & & \multicolumn{2}{|c|}{ Recruitment efficiency } & \multicolumn{2}{|c|}{ Positive affective climate } & \multicolumn{2}{|c|}{ Firm performance } \\
\hline & & B & SE & B & SE & B & SE \\
\hline Constant & & $3.32 * * *$ & .76 & $2.63 * * *$ & .21 & $.13 * * *$ & .77 \\
\hline \multirow[t]{11}{*}{ 1. Control variables } & High performance work practices (HPWPs) & -.11 & .11 & .06 & .03 & -.13 & .08 \\
\hline & Ambidextrous management practices & -.20 & .12 & -.01 & .03 & $.33 * * *$ & .06 \\
\hline & Transformational leadership CEO & .22 & .10 & $.12 * * *$ & .03 & -.08 & .08 \\
\hline & Company size (log) & -.22 & .11 & $-.09 * *$ & .03 & -.01 & .07 \\
\hline & Workforce mean age & -.11 & .09 & -.03 & .03 & .00 & .06 \\
\hline & Workforce age diversity & -.09 & .10 & .00 & .02 & .04 & .06 \\
\hline & Environmental dynamism & -.01 & .10 & -.04 & .02 & $-.22 * * *$ & .05 \\
\hline & Local economic situation & -.01 & .10 & .03 & .03 & .09 & .07 \\
\hline & Recruiting difficulties & $-.42 * * *$ & .10 & $-.06 *$ & .03 & .13 & .08 \\
\hline & Industry: Manufacturing & -.19 & .14 & .03 & .04 & $-.25^{*}$ & .09 \\
\hline & Industry: Service & -.20 & .13 & .02 & .04 & $-.32 * *$ & .09 \\
\hline \multirow[t]{3}{*}{ 2. Main effects } & Employer branding orientation & $.31 *$ & .13 & $.12 * *$ & .04 & .06 & .08 \\
\hline & Positive affective climate & - & - & - & - & $.66^{*}$ & .31 \\
\hline & Recruitment efficiency & - & - & - & - & .16 & .08 \\
\hline$R^{2}$ & & $.28 * *$ & & $.49 * * *$ & & $.42 *$ & \\
\hline
\end{tabular}

Note: $\mathrm{N}=93$.

$* p<.05 ; * * p<.01 ; * * * p<.001$. 
Second, a model with no control variables also resulted in similar and significant (at a 5\% level, two-sided) effects for all significant relationships from the main analysis. This signifies that our results did not depend on the inclusion or exclusion of specific control variables.

Third, we inspected a model in which we included all further variables from the above-mentioned further paper using the same dataset as control variables in our model. In total, we added eight further control variables to our model (health-related HRM, employees' stress mindset, collective organizational engagement, TFL climate, industry trade dummy, collective emotional exhaustion, mean company tenure, and coworker support). In this alternative model, there was a positive relationship between employer branding orientation and positive affective climate $(B=.06, t=3.45, p<.01)$, and between positive affective climate and firm performance $(B=.79, t=1.98, p<.05)$. The indirect effect of employer branding on firm performance via positive affective climate was not significant within a $95 \%$ confidence interval $(B=.06$; $95 \% \mathrm{BCCl}[-.009, .145])$ but within a $90 \%$ confidence interval $(B=.06$; $90 \% \mathrm{BCCl}[.001, .127])$. These results indicate that our main findings from the initial analyses remain constant, despite including the variables from the above-mentioned further paper as control variables.

Finally, we also replicated our findings with a more objective performance measure. For that purpose, we collected data on the annual net profit of the participating companies from the balance sheet that many German companies need to publish in an official publicly available online portal (www.bundesanzeiger.de). We calculated the delta of the net profit of the year of the survey and the following year to account for the increase or decrease of the profit in the period after our survey. Given legal reporting standards in Germany, not all of the companies had to report their net profits (or net losses), which resulted in a reduced sample size of 41 companies. To obtain reliable estimates also for this smaller sample size, we did not include all 12 control variables from the main analyses, but only those six that showed a significant relationship to any of the three mediators or outcome variables. As common for such objective performance measures with companies of different sizes, the data distribution was heavily skewed. Since we had positive and negative values (in case of net losses) we could not apply a log transformation to the data but had to apply a so-called Johnson transformation that can deal with positive and negative values (Chou, Polansky, \& Mason, 1998) to obtain a normal distribution of the outcome measure. The results of this robustness test indicate there was a positive relationship between employer branding orientation and positive affective climate $(B=.14, t=2.45$, $p<.05$ ), and between positive affective climate and net profits $(B=.96, t=3.00, p<.01)$. The indirect effect of employer branding orientation on performance via positive affective climate was not significant within a 95\% confidence interval $(B=.12 ; 95 \% \mathrm{BCCl}[-.012$, $.444])$, but within a $90 \%$ confidence interval $(B=.12 ; 95 \% \mathrm{BCCl}$ $[.003, .378])$.

In sum, these robustness tests indicate that the observed mediation effect of employer branding orientation via positive affective climate on firm performance, that we found in the main analyses, is robust among a multiple number of alternative model solutions and measures, further increasing the confidence in our results.

\section{DISCUSSION}

Our study integrates brand marketing research with HRM theory to build a mediated model of the effect of employer branding on HRM outcomes and firm performance. The present findings by and large lend support to the assumed (e.g., Backhaus \& Tikoo, 2004; Edwards, 2010; Mosley, 2014)-but, as yet, not theorized and tested-positive effect of employer branding on HRM outcomes and, partly, firm performance at the firm level of analysis. Using the employer branding value chain model (Theurer et al., 2018) as a guiding theoretical framework, we conceptualize and test a mediation model explicating the effects of employer branding orientation on firm performance through recruitment efficiency and positive affective climate. We find support for most of the proposed relationships using a multisource firm-level design while controlling for a comprehensive set of HPWP and other central control variables (Datta et al., 2005). We find employer branding orientation directly affects both recruitment efficiency and positive affective climate. Importantly, we find differentiating indirect effects of employer branding orientation on firm performance: employer branding orientation indirectly influences firm performance via the internal route (i.e., incumbent employees' positive affective climate), but not via the external route (i.e., recruitment efficiency). Thus, complementing existing employer branding research, we show that although employer branding does influence recruitment efficiency, the positive effects on firm performance emerge via the internal route, that is, positive affective climate rather than via the external route, that is, recruitment efficiency. Moreover, we do not find a positive relationship between recruitment efficiency and firm performance. The few extant studies that have investigated the link between recruitment variables and firm performance (e.g., Greer et al., 2016; Sheehan, 2014), generally do show positive effects, and, thus, our finding is not in line with these results. We speculate our nonsignificant findings in this regard might be due to our global perceptual measure of recruitment efficiency based on Likert-type scales rather than the use of objective data from the HR information system (we discuss this issue in more detail in the limitations section).

Our study makes a contribution to management research in a broader sense by demonstrating how insights from marketing, in particular, branding orientation, brand equity, and the brand value chain model (Baumgarth, Merrilees, \& Urde, 2013; Keller \& Lehmann, 2006; Urde, 1999) can be fruitfully combined with HRM theory to yield firm-level explanations of HRM outcomes and firm performance.

Our study contributes to the HRM literature by conceptualizing employer branding as a guiding HR principle (Becker \& Gerhart, 1996; Jackson et al., 2014; Jiang et al., 2012), which enables us to examine whether the effect of employer branding on firm-level outcomes is generalizable, that is, independent of concrete brand attributes or practices. In line with Becker and Gerhart (1996; see also Colbert, 2004), we show that employer branding as a "best practice" enhances key HR outcomes and firm performance. Whereas previous research focusing on brand attributes answers the question of to what extent applicants perceive the specific brand attributes examined in a 
particular context (e.g., "sincerity" or "ruggedness" in the banking or fast food industries) as attractive, our study generalizes beyond concrete attributes to answer the question of whether engaging in employer branding has a generalizable effect on HR outcomes and firm performance (Becker \& Gerhart, 1996). Our study thus takes into account the idea that successful branding may be achieved in different ways depending on the specific firm context (Grohs, Raies, Koll, \& Mühlbacher, 2016). Our research hence provides insight on the question of whether an employer branding orientation as a general approach to HRM, that is, "applying brand thinking to people management" (Mosley, 2014, p. 1) is connected to firm performance.

Moreover, our approach of conceptualizing employer branding as a guiding HR principle (Becker \& Gerhart, 1996) also advances research by making it possible to test the underlying mediational mechanisms that potentially connect employer branding with firm performance. Building on the employer branding value chain model (Theurer et al., 2018), we hypothesize that employer branding may not only affect application-related outcomes, as has been the focus in the majority of extant employer branding research but also on incumbent employees' engagement. In fact, our empirical results show that the effect via the internal route is even stronger than via the external route. We thus contribute to current theory by developing a holistic approach-empirically testing both routes at the same time in one model-to explain employer branding's effect on firm performance. In so doing, we answer outstanding calls in the literature (Ambler \& Barrow, 1996; Backhaus \& Tikoo, 2004; Phillips \& Gully, 2015) to investigate these effects and the mediational mechanisms through which they are achieved. We directly respond to these calls and show an effect of employer branding even when controlling for multiple HPWP and additional control variables, which strengthens the role of employer branding research in the broader field of HRM.

Furthermore, by shifting our theorizing and analysis of employer branding to the firm level of analysis, our approach enables us to provide evidence on the firm-level mediating mechanisms connecting employer branding and firm performance. While previous research has (with notable exceptions; e.g., Collins \& Han, 2004; Turban \& Cable, 2003) mainly focused on the individual-level outcomes of employer brand characteristics (e.g., Cable \& Turban, 2003; Lievens, 2007; Van Hoye et al., 2013), we advance the field by examining the mechanisms underlying its firm performance effects.

Our study also contributes to the field by advancing the scant but emerging research on emotions in employer branding (Rampl, 2014; Rampl et al., 2016) by investigating collective emotions, that is, in our case: positive affective climate, as a mediator. Whereas emotions have often been implicitly conceptualized in prior employer branding studies, there is a lack of explicit theorizing, modeling, and empirically testing its effects (Lievens \& Slaughter, 2016). Our study addresses this void and contributes beyond existing studies-which have mainly been conducted at the individual level of analysis-by demonstrating that employer branding impacts positive affective climate at the firm level, and that this positive affective climate may translate into firm performance.
Overall, our research brings forward the emerging brand equity perspective in HRM (Cable \& Turban, 2001; Collins \& Kanar, 2014) by gearing the research focus toward examining employer branding effects beyond the target group of applicants toward incumbent employees, and, ultimately, firm performance. We thus open new theoretical and empirical avenues for employer branding research by concentrating on tangible firm outcomes and their effects when building an effective employer brand (Backhaus \& Tikoo, 2004). Because the extant research perspective has had a strong focus on single employer brand attributes (e.g., Van Hoye et al., 2013), this internal mechanism perspective is important for extending our knowledge on the consequences of employer brand building at a strategic level. Our research thus contributes to viewing employer branding as a strategic firmlevel approach (Jiang et al., 2012) by focusing on its firm-level outcomes.

\subsection{Practical implications}

In terms of practical implications, our findings imply that employer branding has benefits in terms of both recruitment efficiency and higher positive affective climate of incumbent employees. Thus, given the vast interest in employer branding in corporate and SME firms, our study may serve as an argument for HR professionals supporting investment in employer branding to enhance these two key HR outcomes. However, we do not find a link between recruitment efficiency and firm performance, and also no indirect effect of employer branding orientation on firm performance through recruitment efficiency (but through positive affective climate). Thus, based on our findings, HRM professionals need to be aware that the positive effect of employer branding orientation on firm performance may be due to its effect on incumbent employees (i.e., positive affective climate; "internal route") rather than recruitment efficiency ("external route"). In this vein, HRM professionals may refer to our results when explaining to their leadership why employer branding may be important and what effects it may have on incumbent employee outcomes, and firm performance. Specifically, our results support an investment in "internal employer branding" (Lievens et al., 2007; Theurer et al., 2018), that is, promoting the employer brand to incumbent employees through firminternal communication channels. Doing so, HR professionals may be able to engage employees around the employer brand as a "platform" to spark positive affective climate. As an example of this practice, the LEGO group uses its employer brand (with its main employer value proposition pillars: "Purpose driven," "Systematic creativity," "Clutch Power," and "Action ability") to engage its employees (Mosley, 2014). Their employer brand is one of four brands developed specifically for different stakeholders (the others being customers, business partners, and the global environment and society), and provides a "common platform" for shaping HRM activities (Mosley, 2014; People in Business, 2016). Thus, in contrast to widely held beliefs in practice that employer branding is purely a recruitment-related activity that is in place to attract applicants (i.e., focusing on recruitment), we demonstrate that the positive effects on firm performance unfold through incumbent employee-related outcomes rather than applicant-related 
outcomes. Because our findings identify the concrete mechanism through which employer branding orientation has a beneficial impact on extant employees' positive engagement, our study enhances HR professionals' understanding of the underlying points of leverage.

\subsection{Limitations and suggestions for future research}

While our study has several strengths, such as the integrative theoretical model, firm-level analysis, and multisource design with three data sources, we also acknowledge several limitations. First, while we base our model on theoretically solid assumptions regarding the proposed causal order of our variables and run a robustness test with a time lagged performance measure, we cannot ultimately derive causal inferences based on our cross-sectional design. To further lower the likelihood of a reversed causal order, we also controlled for an endogeneity bias, as selection effects and uncontrolled confounding variables are a main threat to causality (Antonakis, Bendahan, Jacquart, \& Lalive, 2010). For this purpose, we performed a Hausmann test for the significant hypotheses from our main analyses applying a two stage least squares (2SLS) estimation, technique. For both Hypothesis 2 (employer orientation $\rightarrow$ positive affective climate, $\chi^{2}: .32, p=.85$ ) and Hypothesis 4 (positive affective climate $\rightarrow$ firm performance, $\chi^{2}$ : $.65, p=.72$ ) this test showed that the 2SLS results were not significantly different from our main results, indicating endogeneity was not a main threat to our reported findings. In sum, these further tests make us confident that a reversed causality is unlikely for our proposed model. Still we would encourage future studies to further establish causality within these posited relationships, for example, by using panel data on the effects of employer branding orientation on firm performance or even by conducting an experimental or quasiexperimental manipulation of employer branding orientation.

Second, our sample consisted mostly of small and medium-sized enterprises (SMEs) in Germany, which might limit the generalizability of our research. However, since SMEs make up most of the economic activity in most developed countries, and because the participating companies represent multiple industries, we may nevertheless assume a decent level of generalizability of our results. Additionally, we argue that the study of employer branding is especially appropriate in SMEs. While large corporations are often publicly well-known due to their size and widespread product brands, SMEs are less familiar to the public and, therefore, need to engage in employer branding to raise awareness of their brands on the labor market (Ewerlin \& Süß, 2016). Thus, employer branding may be even more important for SMEs than for large corporations. Moreover, while we theoretically employ a "universalistic" perspective (Delery \& Doty, 1996)-assuming more employer branding orientation will always contribute to higher firm performance (irrespective of a certain firm strategy or certain HR practice configuration) than less or no employer branding orientation-we are not able to test whether our findings apply to any firm (e.g., large firms or startups). Therefore, we encourage future studies to investigate employer branding orientation at a strategic level in other organizational contexts to examine whether our relationships can be replicated in settings outside the SME context (e.g., larger firms above 5,000 employees).

Third, our perceptual measures might raise concerns regarding the accuracy and validity of our study. For the firm performance measure, we addressed this issue by replicating our findings with an objective net-profit measure in a smaller subsample. Still, for both the employer branding orientation measure and the recruitment efficiency measure, our data collection strategy with surveying one or several key informants per company (i.e., top HR representatives or members of the TMT) might raise concerns about the reliability and validity of theses scales. Regarding the employer branding orientation measurement, it would be ideal to also assess actual employer brand performance resulting from employer branding orientation using external sources (e.g., external applicants or current employees) to validate the assessment of the top HR representatives. We therefore encourage such multisource assessment in future research. To assess recruitment efficiency, it would be desirable to obtain process generated information from the firms' HR and accounting systems (e.g., actual time to fill a position, actual calculated cost to fill a position) to get a more objective assessment of the recruitment processes. We would also speculate our global assessment of recruitment efficiency might have affected the predictive validity of this measure and might thus be one of the explanations for the observed nonsignificant relationship between recruitment efficiency and firm performance. Consequently, we highly encourage future research using more objective recruitment measures, although we acknowledge that such data might be difficult to collect in a multicompany sample.

\section{CONCLUSION}

In conclusion, our research offers a model of the effects of strategic engagement in employer branding at the firm level. In addition to demonstrating the positive effects of employer branding orientation on recruitment efficiency and positive affective climate, our findings yield differentiating mediating effects by showing that positive affective climate rather than recruitment efficiency functions as the mediating mechanism linking employer branding orientation with firm performance. Given the widespread use of employer branding in today's HRM practice, our research aids in conceptually clarifying the relationships underlying the effects of employer branding. We hope that our study will stimulate further theory and empirical research on the firm-level effects of employer branding.

\section{ENDNOTES}

${ }^{1}$ One further paper has used the same dataset. There is only one variable overlap (i.e., firm performance) between the two papers and no bivariate relationships are investigated in both papers. Nonetheless, we carefully addressed this issue through robustness tests in which we replicated our findings in a model including all variables from the other paper as controls (for more details, see Results section).

2 This procedure was applied to limit the amount of questions that each employee had to answer for the overall benchmarking study. There were 
four other employee surveys with randomly selected $25 \%$ of the employees that were not used for this study.

${ }^{3}$ We included recruitment difficulties as a control variable for two reasons. First, this global measure of hiring success taps the state of the recruitment processes that might be affected by both external factors (e.g., difficulties to attract candidates due to rural company location) and internal factors (e.g., inefficient recruiting procedures). We thus assume that this measure should be a driver of recruitment efficiency (measured as the internal efficiency of recruitment processes) and firm performance. Second, as this measure was assessed by the top HR representative in each company, it also offers us the opportunity to cross-validate the recruitment efficiency measure that was assessed by members of the top management team in each firm. In line with theoretical expectations, the recruitment difficulty is negatively and significantly related to recruitment efficiency (-.35**; see Table 1$)$, indicating that the TMT members indeed assess recruitment related processes. Further, the moderate correlation size also indicates that both measures are tapping different concepts.

${ }^{4}$ We did not test our full model with SEM procedures, due to our relatively small sample size, which might lead to unreliable results (Westland, 2010). In a robustness check, however, we show that all our results also remained constant when tested with SEM procedures.

\section{ORCID}

Andranik Tumasjan (D) https://orcid.org/0000-0002-0127-8499

Florian Kunze (D) https://orcid.org/0000-0002-2583-6221

\section{REFERENCES}

Aaker, J., \& Fournier, S. (1995). A brand as a character, a partner and a person: Three perspectives on the question of brand personality. In F. R. Kardes \& M. Sujan (Eds.), Advances in consumer research (Vol. 22, pp. 391-395). Provo, UT: Association for Consumer Research.

Aaker, J. (1997). Dimensions of brand personality. Journal of Marketing Research, 34(3), 347-356.

Akaike, H. (1987). Factor analysis and AIC. Psychometrika, 52, 317-332.

Ambler, T., \& Barrow, S. (1996). The employer brand. Journal of Brand Management, 4, 185-206.

Antonakis, J., Bendahan, S., Jacquart, P., \& Lalive, R. (2010). On making causal claims: A review and recommendations. Leadership Quarterly, 21, 1086-1120.

Ashkanasy, N. M., \& Dorris, A. D. (2017). Emotions in the workplace. Annual Review of Organizational Psychology and Organizational Behavior, 4, 67-90.

Ashkanasy, N. M., Troth, A. C., Lawrence, S. A., \& Jordan, P. J. (2017). Emotions and emotional regulation in HRM: A multi-level perspective. In Research in Personnel and Human Resources Management (pp. 1-52). Bingley, England: Emerald Publishing Limited.

Baas, M., De Dreu, C. K., \& Nijstad, B. A. (2008). A meta-analysis of 25 years of mood-creativity research: Hedonic tone, activation, or regulatory focus? Psychological Bulletin, 134, 779-886.

Backhaus, K. B., \& Tikoo, S. (2004). Conceptualizing and researching employer branding. Career Development International, 9, 501-517.

Bangerter, A., Roulin, N., \& König, C. J. (2012). Personnel selection as a signaling game. Journal of Applied Psychology, 97, 719-738.

Baron, R. A., \& Tang, J. (2011). The role of entrepreneurs in firm-level innovation: Joint effects of positive affect, creativity, and environmental dynamism. Journal of Business Venturing, 26, 49-60.

Barrick, M. R., Thurgood, G. R., Smith, T. A., \& Courtright, S. H. (2015). Collective organizational engagement: Linking motivational antecedents, strategic implementation, and firm performance. Academy of Management Journal, 58, 111-135.

Baum, M., \& Kabst, R. (2013). How to attract applicants in the Atlantic versus the Asia-Pacific region? A cross-national analysis on China, India, Germany, and Hungary. Journal of World Business, 48, 175-185.

Baumgarth, C., Merrilees, B., \& Urde, M. (2013). Brand orientation: Past, present, and future. Journal of Marketing Management, 29, 973-980.

Becker, B., \& Gerhart, B. (1996). The impact of human resource management on organizational performance: Progress and prospects. Academy of Management Journal, 39, 779-801.

Becker, B., Huselid, M. A., \& Ulrich, D. (2001). The HR scorecard: Linking people, strategy, and performance. Boston, MA: Harvard Business School Press.

Berthon, P., Ewing, M., \& Hah, L. L. (2005). Captivating company: dimensions of attractiveness in employer branding. International Journal of Advertising, 24, 151-172.

Bliese, P. D. (2000). Within group agreement, non-independence, and reliability. In K. J. Klein \& S. W. Kozlowski (Eds.), Multilevel theory, research, and methods in organizations (pp. 349-381). San Francisco, CA: Jossey-Bass.

Bowen, D. E., \& Ostroff, C. (2004). Understanding HRM-firm performance linkages: The role of the "strength" of the HRM system. Academy of Management Review, 29(2), 203-221.

Braddy, P. W., Meade, A. W., \& Kroustalis, C. M. (2006). Organizational recruitment website effects on viewers' perceptions of organizational culture. Journal of Business and Psychology, 20, 525-543.

Cable, D. M., \& Graham, M. E. (2000). The determinants of job seekers' reputation perceptions. Journal of Organizational Behavior, 21(8), 929-947.

Cable, D. M., \& Turban, D. B. (2001). Establishing the dimensions, sources, and value of job seekers' employer knowledge during recruitment. Research in Personnel and Human Resources Management, 20, 115-164.

Cable, D. M., \& Turban, D. B. (2003). The value of organizational reputation in the recruitment context: A brand-equity perspective. Journal of Applied Social Psychology, 33, 2244-2266.

Chaudhuri, A., \& Holbrook, M. B. (2001). The chain of effects from brand trust and brand affect to brand performance: The role of brand loyalty. Journal of Marketing, 65, 81-93.

Cheney, G., Christensen, L. T., Conrad, C., \& Lair, D. J. (2004). Corporate rhetoric as organizational discourse. In D. Grant, C. Hardy, C. Oswick, N. Phillips, \& L. L. Putnam (Eds.), Handbook of organizational discourse (pp. 79-103). London, England: Sage.

Chou, Y.-M., Polansky, A. M., \& Mason, R. L. (1998). Transforming nonnormal data to normality in statistical process control. Journal of Quality Technology, 30, 133-141.

Christensen, L. T. (1997). Marketing as auto-communication. Consumption, Markets and Culture, 1, 197-227.

Colbert, B. A. (2004). The complex resource-based view: Implications for theory and practice in strategic human resource management. Academy of Management Review, 29, 341-358.

Collings, D. G., \& Mellahi, K. (2009). Strategic talent management: A review and research agenda. Human Resource Management Review, 19, 304-313.

Collins, C. J., \& Han, J. (2004). Exploring applicant pool quantity and quality: The effects of early recruitment practice strategies, corporate advertising, and firm reputation. Personnel Psychology, 57, 685-717.

Collins, C. J., \& Kanar, A. (2014). In K. Y. T. Yu \& D. M. Cable (Eds.), Oxford handbook of recruitment Employer brand equity and recruitment research (pp. 284-297). New York, NY: Oxford University Press.

Collins, C. J., \& Stevens, C. K. (2002). The relationship between early recruitment-related activities and the application decisions of new labor-market entrants: A brand equity approach to recruitment. Journal of Applied Psychology, 87, 1121-1133. 
Combs, J., Liu, Y., Hall, A., \& Ketchen, D. (2006). How much do high performance work practices matter? A meta analysis of their effects on organizational performance. Personnel Psychology, 59, 501-528.

Datta, D. K., Guthrie, J. P., \& Wright, P. M. (2005). Human resource management and labor productivity: Does industry matter? Academy of Management Journal, 48, 135-145.

Delaney, J. T., \& Huselid, M. A. (1996). The impact of human resource management practices on perceptions of organizational performance. Academy of Management Journal, 39, 949-969.

Delery, J. E., \& Doty, D. H. (1996). Modes of theorizing in strategic human resource management: Tests of universalistic, contingency, and configurational performance predictions. Academy of Management Journal, 39, 802-835.

Delery, J. E., \& Roumpi, D. (2017). Strategic human resource management, human capital and competitive advantage: Is the field going in circles? Human Resource Management Journal, 27(1), 1-21.

Dineen, B. R., \& Allen, D. G. (2016). Third party employment branding: Human capital inflows and outflows following "Best Places to Work" certifications. Academy of Management Journal, 59, 90-112.

Dineen, B. R., \& Williamson, I. O. (2012). Screening-oriented recruitment messages: Antecedents and relationships with applicant pool quality. Human Resource Management, 51, 343-360.

Edwards, M. R. (2010). An integrative review of employer branding and OB theory. Personnel Review, 39, 5-23.

Edwards, M. R. (2017). Employer branding and talent manegement. In D. G. Collings, W. F. Cascio, \& K. Mellahi (Eds.), Oxford handbook of talent management (pp. 233-248). Oxford, England: Oxford University Press.

Edwards, M. R., \& Edwards, T. (2013). Employee responses to changing aspects of the employer brand following a multinational acquisition: $\mathrm{A}$ longitudinal study. Human Resource Management, 52, 27-54.

Ewerlin, D., \& Süß, S. (2016). Dissemination of talent management in Germany: Myth, facade or economic necessity? Personnel Review, 45, 142-160.

Francis, H., \& Reddington, M. (2012). Employer branding and organisational effectiveness. In H. Francis, L. Holbeche, \& M. Reddington (Eds.), People and organisational development: A new agenda for organisational effectiveness (pp. 260-285). London, England: CIPD.

Fredrickson, B. L. (2003). The value of positive emotions: The emerging science of positive psychology is coming to understand why it's good to feel good. American Scientist, 91, 330-335.

Fredrickson, B. L. (2004). The broaden-and-build theory of positive emotions. Philosophical Transactions of the Royal Society B: Biological Sciences, 359, 1367-1377.

Gardner, T. M., Erhardt, N. L., \& Martin-Rios, C. (2011). Rebranding employment branding: Establishing a new research agenda to explore the attributes, antecedents, and consequences of workers' employment brand knowledge. Research in Personnel and Human Resources Management, 30, 253-304.

Gerhart, B. (2007). Horizontal and vertical fit in human resource systems. In C. Ostroff \& T. A. Judge (Eds.), Perspectives on organizational fit (pp. 317-348). New York, NY: Psychology Press.

Gibson, C. B., \& Birkinshaw, J. (2004). The antecedents, consequences, and mediating role of organizational ambidexterity. Academy of Management Journal, 47, 209-226.

Greer, C. R., Carr, J. C., \& Hipp, L. (2016). Strategic staffing and small-firm performance. Human Resource Management, 55(4), 741-764.

Grohs, R., Raies, K., Koll, O., \& Mühlbacher, H. (2016). One pie, many recipes: Alternative paths to high brand strength. Journal of Business Research, 69, 2244-2251.

Guest, D. E., Michie, J., Conway, N., \& Sheehan, M. (2003). Human resource management and corporate performance in the UK. British Journal of Industrial Relations, 41(2), 291-314.
Gully, S. M., Phillips, J. M., \& Kim, M. S. (2014). In K. Y. T. Yu \& D. Cable (Eds.), Oxford handbook of recruitment Strategic recruitment: A multilevel perspective (pp. 161-183). New York, NY: Oxford University Press.

Han, J., \& Ling, J. (2016). Emotional appeal in recruitment advertising and applicant attraction: Unpacking national cultural differences. Journal of Organizational Behavior, 37(8), 1202-1223.

Hanin, D., Stinglhamber, F., \& Delobbe, N. (2013). The impact of employer branding on employees: The role of employment offering in the prediction of their affective commitment. Psychologica Belgica, 53, 57-83.

Hayes. (2017). Introduction to Mediation, Moderation, and Conditional Process Analysis: A regression-based approach. New York, NY: Guilford Press.

Herrbach, O. (2006). A matter of feeling? The affective tone of organizational commitment and identification. Journal of Organizational Behavior, 27, 629-643.

Holtbrügge, D., Friedmann, C. B., \& Puck, J. F. (2010). Recruitment and retention in foreign firms in India: A resource-based view. Human Resource Management, 49, 439-455.

Hu, L., \& Bentler, P. M. (1999). Cutoff criteria for fit indexes in covariance structure analysis: Conventional criteria versus new alternatives. Structural Equation Modeling, 6, 1-55.

Huselid, M. A. (1995). The impact of human resource management practices on turnover, productivity, and corporate financial performance. Academy of Management Journal, 38, 635-672.

Jackson, S. E., Schuler, R. S., \& Jiang, K. (2014). An aspirational framework for strategic human resource management. Academy of Management Annals, 8, 1-56.

James, L. R., Demaree, R. G., \& Wolf, G. (1984). Estimating within-group interrater reliability with and without response bias. Journal of Applied Psychology, 67, 219-229.

Jansen, J. J., Van Den Bosch, F. A., \& Volberda, H. W. (2006). Exploratory innovation, exploitative innovation, and performance: Effects of organizational antecedents and environmental moderators. Management Science, 52, 1661-1674.

Jiang, K., Lepak, D. P., Han, K., Hong, Y., Kim, A., \& Winkler, A. L. (2012). Clarifying the construct of human resource systems: Relating human resource management to employee performance. Human Resource Management Review, 22, 73-85.

Keller, K. L. (1993). Conceptualizing, measuring, and managing customerbased brand equity. Journal of Marketing, 57, 1-22.

Keller, K. L., \& Lehmann, D. R. (2006). Brands and branding: Research findings and future priorities. Marketing Science, 25, 740-759.

Kenny, D. A., Kashy, D. A., \& Bolger, N. (1998). Data analysis in social psychology. In D. Gilbert, S. Fiske, \& G. Lindzey (Eds.), The Handbook of Social Psychology (4th ed., pp. 233-265). New York: McGraw-Hill.

Kim, Y., \& Ployhart, R. E. (2014). The effects of staffing and training on firm productivity and profit growth before, during, and after the Great Recession. Journal of Applied Psychology, 99(3), 361-389.

Knight, A. P., Menges, J. I., \& Bruch, H. (2018). Organizational affective tone: A meso perspective on the origins and effects of consistent affect in organizations. Academy of Management Journal, 61(1), 191-219.

Kozlowski, S. W. J., \& Klein, K. J. (2000). A multilevel approach to theory and research in organizations: Contextual, temporal, and emergent processes. In K. J. Klein \& S. W. J. Kozlowski (Eds.), Multilevel theory, research, and methods in organizations: Foundations, extensions, and new directions (pp. 3-90). San Francisco, CA: Jossey-Bass.

Kunze, F., Boehm, S., \& Bruch, H. (2013). Organizational performance consequences of age diversity: Inspecting the role of diversity-friendly HR policies and top managers' negative age stereotypes. Journal of Management Studies, 50, 413-442.

Kunze, F., Boehm, S. A., \& Bruch, H. (2011). Age diversity, age discrimination climate and performance consequences-A cross organizational study. Journal of Organizational Behavior, 32, 264-290. 
Kunze, F., \& Menges, J. I. (2017). Younger supervisors, older subordinates: An organizational-level study of age differences, emotions, and performance. Journal of Organizational Behavior, 38, 461-486.

Laumer, S., Maier, C., \& Eckhardt, A. (2015). The impact of business process management and applicant tracking systems on recruiting process performance: An empirical study. Journal of Business Economics, 85, 421-453.

Lepak, D., Liao, H., Chung, Y., \& Harden, E. (2006). A conceptual review of human resource management systems in strategic human resource management research. In J. J. Martocchio (Ed.), Research in personnel and human resources management (Vol. 25, pp. 217-271). Oxford, England: Elsevier.

Lepak, D. P., \& Snell, S. A. (2002). Examining the human resource architecture: The relationships among human capital, employment, and human resource configurations. Journal of Management, 28, 517-543.

Lievens, F. (2007). Employer branding in the Belgian Army: The importance of instrumental and symbolic beliefs for potential applicants, actual applicants, and military employees. Human Resource Management, 46, 51-69.

Lievens, F., \& Highhouse, S. (2003). The relation of instrumental and symbolic attributes to a company's attractiveness as an employer. Personnel Psychology, 56, 75-102.

Lievens, F., \& Slaughter, J. (2016). Employer image and employer branding: What we know and what we need to know. Annual Review of Organizational Psychology and Organizational Behavior, 3, 407-440.

Lievens, F., Van Hoye, G., \& Anseel, F. (2007). Organizational identity and employer image: Towards a unifying framework. British Journal of Management, 18, 45-59.

Liu, X. Y., Härtel, C. E., \& Sun, J. J. M. (2014). The workgroup emotional climate scale: Theoretical development, empirical validation, and relationship with workgroup effectiveness. Group \& Organization Management, 39(6), 626-663.

Martin, G., Beaumont, P., Doig, R., \& Pate, J. (2005). Branding: A new performance discourse for HR? European Management Journal, 23(1), 76-88.

Martin, G., Gollan, P. J., \& Grigg, K. (2011). Is there a bigger and better future for employer branding? Facing up to innovation, corporate reputations and wicked problems in SHRM. International Journal of Human Resource Management, 22, 3618-3637.

Martins, P., \& Lima, F. (2006). External recruitments and firm performance. Applied Economics Letters, 13, 911-915.

Maxwell, R., \& Knox, S. (2009). Motivating employees to "live the brand": A comparative case study of employer brand attractiveness within the firm. Journal of Marketing Management, 25, 893-907.

Menges, J. I., \& Kilduff, M. (2015). Group emotions: Cutting the Gordian knots concerning terms, levels of analysis, and processes. Academy of Management Annals, 9, 845-928.

Menges, J. I., Walter, F., Vogel, B., \& Bruch, H. (2011). Transformational leadership climate: Performance linkages, mechanisms, and boundary conditions at the organizational level. Leadership Quarterly, 22, 893-909.

Monks, K., Kelly, G., Conway, E., Flood, P., Truss, K., \& Hannon, E. (2013). Understanding how HR systems work: The role of HR philosophy and HR processes. Human Resource Management Journal, 23, 379-395.

Moser, K. J., Tumasjan, A., \& Welpe, I. M. (2017). Small but attractive: Dimensions of new venture employer attractiveness and the moderating role of applicants' entrepreneurial behaviors. Journal of Business Venturing, 32, 588-610.

Mosley, R. (2014). Employer branding: Practical lessons from the world's leading employers. Hoboken, NJ: Wiley.

Münstermann, B., Eckhardt, A., \& Weitzel, T. (2009). Join the standard forces: Examining the combined impact of process and data standards on business process performance. Paper presented at IEEE Proceedings of the 42nd Hawaii International Conference, 1-10.

Ostroff, C., \& Bowen, D. E. (2000). Moving HR to a higher level: HR practices and organizational effectiveness. In K. Klein \& S. W. J. Kozlowski
(Eds.), Multilevel theory, research, and methods in organizations: Foundations, extensions, and new directions (pp. 221-266). San Francisco, CA: Jossey-Bass.

Ostroff, C., \& Bowen, D. E. (2004). Understanding HRM-firm performance linkages: The role of the "strength" of the HRM system. Academy of Management Review, 29(2), 203-221.

Ostroff, C., \& Bowen, D. E. (2016). Reflections on the 2014 decade award: Is there strength in the construct of HR system strength? Academy of Management Review, 41(2), 196-214.

Paauwe, J. (2009). HRM and performance: Achievements, methodological issues and prospects. Journal of Management Studies, 46(1), 129-142.

Parke, M. R., \& Seo, M. G. (2017). The role of affect climate in organizational effectiveness. Academy of Management Review, 42(2), 334-360.

Patterson, M., Warr, P., \& West, M. (2004). Organizational climate and company productivity: The role of employee affect and employee level. Journal of Occupational and Organizational Psychology, 77, 193-216.

Peccei, R., \& Van De Voorde, K. (2019). The application of the multilevel paradigm in human resource management-outcomes research: Taking stock and going forward. Journal of Management, 45(2), 786-818.

People in Business. (2016). LEGO case study. Retrieved from http://www. people-in-business.com/our-clients/\#/case-studies/

Phillips, J. M., \& Gully, S. M. (2015). Multilevel and strategic recruiting Where have we been, where can we go from here. Journal of Management, 41, 1416-1445.

Podsakoff, P. M., MacKenzie, S. B., \& Podsakoff, N. P. (2012). Sources of method bias in social science research and recommendations on how to control it. Annual Review of Psychology, 63, 539-569.

Posthuma, R. A., Campion, M. C., Masimova, M., \& Campion, M. A. (2013). A high performance work practices taxonomy integrating the literature and directing future research. Journal of Management, 39, 1184-1220.

Rampl, L. V. (2014). How to become an employer of choice: Transforming employer brand associations into employer first-choice brands. Journal of Marketing Management, 30, 1486-1504.

Rampl, L. V., Opitz, C., Welpe, I. M., \& Kenning, P. (2016). The role of emotions in decision-making on employer brands: Insights from functional magnetic resonance imaging (fMRI). Marketing Letters, 27, 361-374.

Rao, H., \& Drazin, R. (2002). Overcoming resource constraints on product innovation by recruiting talent from rivals: A study of the mutual fund industry, 1986-1994. Academy of Management Journal, 45, 491-507.

Renkema, M., Meijerink, J., \& Bondarouk, T. (2017). Advancing multilevel thinking in human resource management research: Applications and guidelines. Human Resource Management Review, 27(3), 397-415.

Rosenbusch, N., Brinckmann, J., \& Bausch, A. (2011). Is innovation always beneficial? A meta-analysis of the relationship between innovation and performance in SMEs. Journal of Business Venturing, 26, 441-457.

Rubin, R. S., Munz, D. C., \& Bommer, W. H. (2005). Leading from within: The effects of emotion recognition and personality on transformational leadership behavior. Academy of Management Journal, 48, 845-858.

Russell, S., \& Brannan, M. J. (2016). "Getting the Right People on the Bus": Recruitment, selection and integration for the branded organization. European Management Journal, 34(2), 114-124.

Saridakis, G., Lai, Y., \& Cooper, C. L. (2017). Exploring the relationship between HRM and firm performance: A meta-analysis of longitudinal studies. Human Resource Management Review, 27(1), 87-96.

Schnars, C. Z., \& Kleiner, B. H. (2000). Best in class staffing practices. Management Research News, 23, 35-38.

Shaw, J. D., Gupta, N., \& Delery, J. E. (2005). Alternative conceptualizations of the relationship between voluntary turnover and organizational performance. Academy of Management Journal, 48, 50-68. 
Sheehan, M. (2014). Human resource management and performance: Evidence from small and medium-sized firms. International Small Business Journal, 32(5), 545-570.

Sung, S. Y., \& Choi, J. N. (2014). Multiple dimensions of human resource development and organizational performance. Journal of Organizational Behavior, 35(6), 851-870.

Taylor, M. S., \& Collins, C. J. (2000). Organizational recruitment: Enhancing the intersection of research and practice. In C. L. Cooper \& E. A. Locke (Eds.), Industrial and organizational psychology: Linking theory and practice (pp. 304-334). Oxford, England: Blackwell.

Terpstra, D. E., \& Rozell, E. J. (1993). The relationship of staffing practices to organizational level measures of performance. Personnel Psychology, 46, 27-48.

Theurer, C., Tumasjan, A., Welpe, I. M., \& Lievens, F. (2018). Employer branding: A brand equity-based literature review and research agenda. International Journal of Management Reviews, 20, 155-179.

Thompson, C. J., Rindfleisch, A., \& Arsel, Z. (2006). Emotional branding and the strategic value of the doppelgänger brand image. Journal of Marketing, 70, 50-64.

Timming, A. R. (2017). Body art as branded labour: At the intersection of employee selection and relationship marketing. Human Relations, 70 (9), 1041-1063.

Tsai, W. C., Chen, C. C., \& Liu, H. L. (2007). Test of a model linking employee positive moods and task performance. Journal of Applied Psychology, 92, 1570-1583.

Tumasjan, A., Strobel, M., \& Welpe, I. M. (2011). Employer brand building for start-ups: Which job attributes do employees value most? Zeitschrift für Betriebswirtschaft, 81, 111-136.

Turban, D. B., \& Cable, D. M. (2003). Firm reputation and applicant pool characteristics. Journal of Organizational Behavior, 24, 733-751.

Ulrich, D. (1997). Measuring human resources: an overview of practice and a prescription for results. Human Resource Management, 36, 303-320.

Urde, M. (1999). Brand orientation: A mindset for building brands into strategic resources. Journal of Marketing Management, 15 117-133.

Van Hoye, G., Bas, T., Cromheecke, S., \& Lievens, F. (2013). The instrumental and symbolic dimensions of organizations' image as an employer: A large-scale field study on employer branding in Turkey. Applied Psychology, 62, 543-557.

Van Katwyk, P. T., Fox, S., Spector, P. E., \& Kelloway, E. K. (2000). Using the Job-Related Affective Well-Being Scale (JAWS) to investigate affective responses to work stressors. Journal of Occupational Health Psychology, 5(2), 219-230.

Wall, T. D., Michie, J., Patterson, M., Wood, S. J., Sheehan, M., Clegg, C. W., \& West, M. (2004). On the validity of subjective measures of firm performance. Personnel Psychology, 57, 95-118.

Westland, J. C. (2010). Lower bounds on sample size in structural equation modeling. Electronic Commerce Research and Applications, 9(6), 476-487.
Wong, H., \& Merrilees, B. (2008). The performance benefits of being brandorientated. Journal of Product and Brand Management, 17, 372-383.

\section{AUTHOR BIOGRAPHIES}

ANDRANIK TUMASJAN is a professor of Management and Digital Transformation at Johannes Gutenberg University Mainz. He received his doctoral degree and his habilitation degree from the Technical University of Munich. His research addresses the impact of digital technologies on general management, organizational behavior, and human resource management.

FLORIAN KUNZE is a Professor for Organisational Studies at the University of Konstanz, Germany. Before he was an Assistant Professor at the University of St. Gallen, Switzerland, where he also completed his dissertation in 2010. His research evolves around leadership and diversity management in teams and companies.

HEIKE BRUCH is a Professor of Leadership and Director of the Institute for Leadership and Human Resource Management at the University of St. Gallen, Switzerland. Her research interests include organizational energy, leaders' action, emotions in organizations, as well as team and organization processes triggered by diversity.

ISABELL M. WELPE holds the Chair of Strategy and Organization at the Technische Universität München in Munich, Germany. Her research interests are in new public management, leadership, future concepts of work and organizations, impact of digital technologies, and social media and strategic innovation. 